\title{
ABNORMAL LOAD TRANSPORT IN THE CONTEXT OF URBAN LOGISTICS
}

\author{
Aleksandra WIERZBICKA ${ }^{1}$, Mariusz KMIECIK ${ }^{2 *}$ \\ ${ }^{1}$ Silesian University of Technology, Zabrze; aleksandra.wierzbicka@polsl.pl, ORCID: 0000-0003-2373-6830 \\ ${ }^{2}$ Silesian University of Technology, Zabrze; mariusz.kmiecik@polsl.pl, ORCID: 0000-0003-2015-1132 \\ * Correspondence author
}

Purpose: The goal of the article is to present oversized transport in the context of urban logistics as the impact of available urban infrastructure, documentation and means of transport on the flow of oversized cargo between the place of loading and the place of receipt. Abnormal load transportation is carried out with the use of public and private roads. It affects the infrastructure and safety of the city through which it takes place, because usually a given section of the road is not excluded during the journey.

Design/methodology/approach: The article is based on a broad analysis of Polish and foreign literature. The article also contains an example of the organization of abnormal load transport by one of the Polish enterprises, which was awarded the prestigious "ESTA Awards of excellence 2017 " in the category of transport over 120 tonnes.

Findings: Oversized transport has a big impact on the temporary functioning of freight flows in the city. The city's spatial development and legal norms significantly influence the oversize transport reduction. It is interesting area of research developing in the future.

Originality/value The article shows oversized transport in the context of the city and freight flows in the city.

Keywords: Oversize transport, Road transport, City transport.

Category of the paper: Research paper, Case study.

\section{Introduction}

Efficient functioning of almost every enterprise is determined by transport in various forms. From the point of view of people running a business, properly organized transport ensures continuity of supply, production and distribution. For the inhabitants of a given region, transport ensures that basic needs are met. Transport has an impact on the development of cities and even the whole country (Landowski et al., 2015). Transport is defined as the total of resources and activities related to the movement of persons and material loads (Kurowski, 2017). In recent 
years, attention has been paid to the impact of transport on environmental issues and sustainable development. People are increasingly aware of existing threats and the consequences of actions that are not in line with nature. The rapid formation of subsequent investment projects generates a demand for the transport of construction elements and machines whose dimensions exceed the permissible transport standards. The largest demand for oversized transport is noticeable in the industrial zone. The development of technology has made it possible to transport larger and heavier components, i.e. wind turbines, military equipment, train locomotives, and bridge spans. In Poland, such transport is usually carried out using road transport, because it is the only branch of transport offering a transport service directly from the place of loading to the destination. Oversized transport involves proper preparation of the conveyance, cargo and transport route. In many cases, the weight or size of commodity causes the need to prepare the road for passage by closing it and/or raising power lines, removing road signs (SzczuckaLasota, 2017).

The goal of the article is to present oversized transport in the context of urban logistics as the impact of available urban infrastructure, documentation and means of transport on the flow of oversized cargo between the place of loading and the place of receipt. The article contains a description of the necessary permits needed for oversized transport and problems related to the organization of the transport route through the city. The article is based on a broad analysis of Polish and foreign literature.

\section{Oversize transport - characteristics}

Analyzing the transport of oversize cargo through the city, you should begin by characterizing what exactly is oversize cargo. An unambiguous definition related to this concept cannot be found in the literature. One definition defines oversize loads as those, whose contours exceed the dimensions of the vehicle or means of transport (Filina, 2008). In practice, this means that for each transport branch there are different guidelines to classify the load as non-standard. In sea transport, undersized loads and those that are not within a certain standard in terms of weight, size or shape are called oversize loads, in road transport abnormal loads, while in rail transport cargo with exceeded loading gauge (Salomon, 2010). Abnormal loads can be divided according to weight and shape (Fig. 1). 


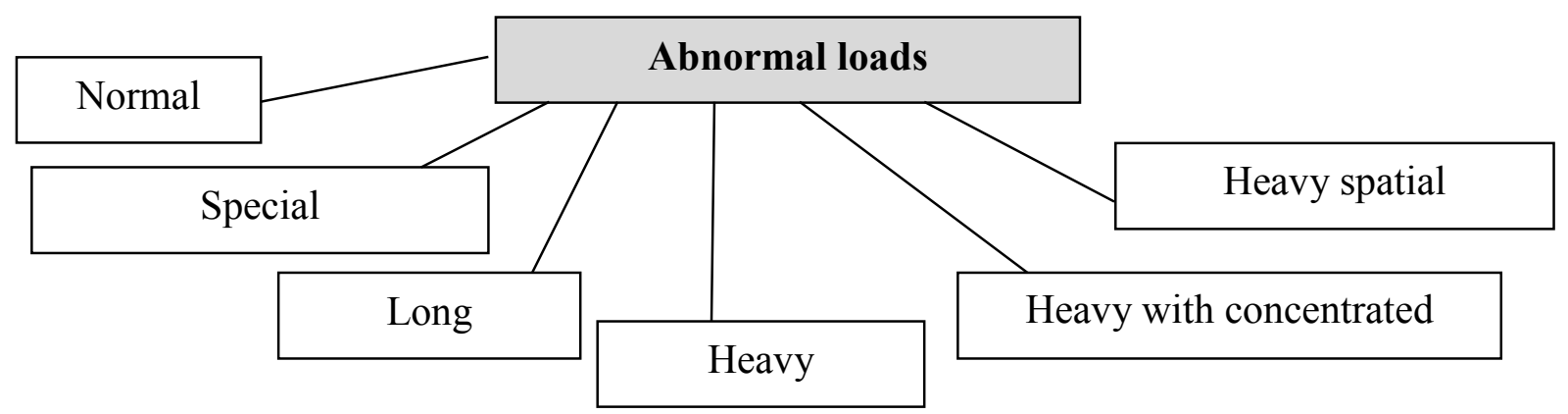

Figure 1. Types of oversize/abnormal loads in road transport.

Normal oversize loads have a weight not exceeding 25 tonnes and are usually transported by road sets equipped with special markings, as they slightly exceed the permitted parameters. An example of such a load is machinery, steel structures and small containers. Oversize special shipments are loads with a relatively small mass, the dimensions of which significantly exceed the acceptable sizes. Heavy spatial loads are not transported by road. Their transport, due to the enormous weight and large dimensions, takes place only by means of ships and barges. Heavy loads with concentrated mass, such as turbines and transformers, are distinguished by their high weight-to-volume ratio. They are transported by land by means of multi-axle railway wagons or multi-axle semitrailers (Salomon, 2017).

Each branch of transport has a different line and point infrastructure, as well as means of transport, which means that the dimensions of oversize loads cannot be standardized. It does occur that a shipment, which is an abnormal load for one means of transport, may turn out to be standard for another (Rudziński, Kowalczyk, 2012). Most often conveyed for oversize transport are bridge spans, military equipment, elements of machine construction used in industry and electric transformers (Durski, 2008). This type of transport requires individual organization and preparation for transport activities. It is important to properly synchronize the stage of preparation and implementation of the service, allowing you to achieve the objective of delivering cargo to the final customer at the right time. In the city, abnormal load transport is most often carried out by road means of transport, for which oversize cargo is referred to when, after loading, its dimensions or weight exceeds the maximum acceptable parameters of a standard road set or a combination with a trailer (Galor, 2010). In road transport, the assignment of a load to a non-standard group is determined by such parameters as: total weight of the set (with load), length, width and height of the set, and axle load. Table 1 presents the acceptable parameters of road freight. 
Table 1.

Load sizes acceptable for road transport

\begin{tabular}{|c|l|}
\hline Criterion & \multicolumn{1}{c|}{ Rules adopted } \\
\hline Length & $\begin{array}{l}\text { - a combination consisting of a motor vehicle and a trailer }-18.75 \mathrm{~m} ; \\
\text { - a combination with a semitrailer (articulated vehicle) }-16.5 \mathrm{~m}\end{array}$ \\
\hline Width & $\begin{array}{l}\text { - for all vehicles }-2.55 \mathrm{~m} ; \\
\text { - for vans (refrigerated) }-2.60 \mathrm{~m}\end{array}$ \\
\hline Height & - maximum $4 \mathrm{~m}$ \\
\hline Total mass & $\begin{array}{l}\text { - for articulated vehicles having } 5 \text { or } 6 \text { axles: } \\
\text { a) two-axle tractor unit and three-axle semitrailer }-40 \text { tonnes, } \\
\text { b) three-axle tractor unit and two- or three-axle semitrailer }-40 \text { tonnes, } \\
\text { c) three-axle tractor unit and three-axle semitrailer transporting a 40-foot ISO container in } \\
\text { combined transport - 44 tonnes }\end{array}$ \\
\hline Axle load & $\begin{array}{l}\text { - the sum of the maximum axle loads must not be less than the maximum gross vehicle weight } \\
\text { and the axle load front with maximum rear axle load and maximum gross vehicle weight must } \\
\text { not be less than 30\% of the maximum total weight }\end{array}$ \\
\hline
\end{tabular}

Source: own study based on: Journal of Laws of the Republic of Poland of 15 December 2016. Notice of the Minister of Infrastructure and Construction of 27 October 2016 on announcing the uniform text of the Regulation of the Minister of Infrastructure on the technical conditions of vehicles and the scope of their obligatory equipment.

The cargo is classified as abnormal when it exceeds one of the above mentioned criteria by one unit. In rail transport, the shipment is considered oversize after exceeding the wagon loading gauge or load per meter of the current wagon or train tracks. Extraordinary shipment in this branch of transport requires special transport rolling stock, as well as loading and unloading methods. For rail transport, the maximum acceptable weight of standard goods is 60 tonnes. It is up to 16 tonnes more than in the case of road transport. The transport capacity of abnormal load shipments by train reaches up to 400 tonnes. Goods exceeding the length of wagons are becoming a problem. Then, the solution are specialized long-rail wagons with mounted pivots that allow turns on curves (Neider, 2012). In the case of abnormal cargo by rail, it is important that the route should not pass through the main passenger stations and urban areas (Rabant, Habel, Babińśki, 2016). In the case of water, sea and inland waterway transport, restrictions mainly apply to transport means, less often to difficulties related to the flow route, e.g. bridge clearances. Inland transport is usually rejected when choosing the method of transporting abnormal cargo by low technical speed (Dyczkowska, 2011). For sea transport, restrictions on the size, weight and other parameters of cargo are practically non-existent. Ships intended for this purpose often have a very large cargo space and load-bearing capacity, making it possible to transit elements, which are classified as abnormal loads for other transport branches (Waniek, 2012). 


\section{Organization of abnormal load transport in the city}

Abnormal load transport, due to its specificity, in addition to the use of specialized tools and means of transport, also requires the considerable involvement of an experienced team of professionals organizing this type of transport. The transport of abnormal cargo through the city, in addition to the written consent of the relevant authorities, also obliges the organizers of the transport to determine the appropriate route and to check it in advance for necessary changes in infrastructure, e.g. temporary removal of some road signs, dismantling a roundabout island ${ }^{1}$. Transport should be planned so that the load gets from the pickup point to the final destination without a collision. The individual responsible for preparing the transport is obliged to check many external factors, i.e. (Salomon, 2018):

- Atmospheric conditions.

- Road conditions.

- Journey time.

- Having the necessary administrative permits.

The customer of the abnormal load transport should actively cooperate with the transport organizer to provide them with all the necessary information for the proper performance of the contract. This information applies to (Salmon, 2018):

- The weight of the load, which will allow the selection of the right type of transport, taking into account its load capacity and designating the necessary number of axles for the road set.

- All shipment dimensions, i.e. length, width and height.

- Type of load, in order to provide a suitable transport vehicle adapted to the type of load. Another type of semitrailer is used when transporting a container, and a different one for transporting an agricultural machine or excavator, although their dimensions and shapes may be similar (Żurawski, 2019).

- Time needed for loading, unloading and delivery of cargo to the recipient.

- Other necessary information to facilitate transport, e.g. the possibility of unscrewing individual elements, the place of admission if the cargo requires it.

Some transports require police piloting or a specialized and licensed pilot car company. It is also worth mentioning that a shipment is considered to be an abnormal load if it is not possible to divide it into smaller elements and if it cannot be transported by a transport branch in which it is considered a standard one.

\footnotetext{
${ }^{1}$ MEGATRANSPORTY, program broadcast on TVN Turbo channel, season 3. 2017.
} 


\section{Transportation of abnormal cargo in the context of the city}

Nowadays, cities are treated as open systems, not as closed units, which is why all transport streams undeniably affect its functioning. A common feature of modern solutions, also from the point of view of urban logistics is their networking. Infrastructure solutions, e.g. roads, but also logistics, e.g. reloading points, logistics centers, are particularly important in the city (Tundys, 2012). The introduction of various amenities in the transport structure in cities is conducive to their efficient functioning and optimization in the transport of goods, including those of abnormal loads (Górniak, 2016). The main task of urban logistics is to implement, control and plan flows directed to the city, transit and inside the city with the accompanying flow of information.

Transport of abnormal cargo is a special type of flow in the city that must be carefully planned and controlled. The passage of a vehicle transporting an abnormal load shipment should not pose a threat to the technical condition of building structures, i.e. residential houses and retail and service outlets located near the route. Ensuring road safety during transport is one of the conditions for a well-planned route passing through the city. The planning process should also take into account the spatial structure of the city or cities, through which the passage is to be made. In particular, it is necessary to check the width of roads, signs and posts on roads, height and width of crossings under viaducts and bridges, roundabouts, allowed vehicle load on surfaces, electric traction, road condition (Waniek, 2012). A serious problem in the transport of oversize cargo through cities is the failure to adapt the urban infrastructure to this type of transport and the lack of solutions used to allow a rapid change in infrastructure. This applies, among others, to intersections with circular traffic, in the middle of which there are usually flower beds, decorative statues or buildings. The transit of abnormal cargo often requires driving onto an island marking a roundabout, due to the vehicle turning curve. All permanent elements are a major impediment to the transport of abnormal load shipments. Transport of abnormal cargo not only has a huge impact on urban agglomerations, but also emits a large amount of harmful and hazardous substances and noise. In addition to that, it affects the volume of traffic, and associated operations, i.e. loading or unloading, often cause traffic problems (Szołtysek, 2009).

\section{Permits in abnormal load transport}

The permit is defined as an administrative decision issued by the relevant local government authorities or the Main Inspectorate of Road Transport allowing the carrier to perform a specific type of road transport (Salomon, 2018). Permission for the transport of oversize loads on public 
roads, especially those passing through the city, should be approved on the basis of special documents. They not only determine the previously designated route, but also give the opportunity to remove any obstacles along the route. The permit is issued to the carrier on the basis of legal acts or in a one-time manner, depending on the category. When planning abnormal load transport, you must specify whether the route will cross public or private roads so that you can apply for a special permit. Documents for categories II and III are approved by the Starost (senior administrative official) or the Customs Office. Permits for category III and IV are issued by the Customs Office or the General Directorate for National Roads and Motorways. Other categories of permits can only be issued by the General Directorate for National Roads and Motorways (Salomon, 2018). It is worth noting that having a permit for a given category entitles you to drive vehicles on roads of a given category and below. There are 7 categories of permits (Meszko, 2017):

I- $\quad$ Allows to travel on roads indicated on the permit, whose weight, size and axle load do not exceed the acceptable value for roads with a drive axle load of up to 11.5 tonnes.

II- Allows to travel on public roads, excluding highways and expressways, whose length, size and axle load do not exceed the acceptable values for a given road, and the width is not more than $3.5 \mathrm{~m}$.

III- Allows to travel on public roads without violating the maximum load and axle load on the road designated to them. The width of the vehicle must not exceed $3.2 \mathrm{~m}$ and the height may not exceed $4.3 \mathrm{~m}$. The length of a single vehicle should not exceed $15 \mathrm{~m}$ and the combination of vehicles $-23 \mathrm{~m}$.

IV- Allows to travel on national roads without violating their maximum load standards. The pressure of a single driving axle should not exceed 11 tonnes. The maximum length and height of the vehicle is the same as in the case of category III, while the width can be up to $3.4 \mathrm{~m}$.

V- Allows the passage of vehicles whose axle load does not exceed the permissible standards on the road for abnormal load vehicles. Other parameters of the size of the laden vehicle are as for category IV.

VI- Allows to drive on roads indicated in the list for abnormal load vehicles. The vehicle width should not be more than $4 \mathrm{~m}$ in the case of a dual carriageway. The maximum height should be $4.3 \mathrm{~m}$, weight 60 tonnes.

VII- Allows for single journey not exceeding 14 days from the date of issue of the document or multiple journeys not exceeding 30 days from the date of issue of the permit within the defined period on public roads, only along the previously designated route. The journey included in category VII requires a lot of organization and commitment on the part of the carrier and the ordering party. 
All journeys of vehicles exceeding the acceptable standards require a special permit. Due to the often long waiting time for issuing a document, some carriers decide to transport without valid permits. This not only causes difficulties and danger in traffic, but also imposes financial penalties on transport organizers. Since 2012, the carrier and the forwarder, as well as the shipper are all responsible for the journey (Salomon, 2012).

\section{An example of abnormal load transport in the context of urban logistics}

An example of a company dealing in freight forwarding and abnormal load transport is MTD Skuratowicz. In 2017, the company was responsible for transporting over a 300 tonne reactor from the port of Klaipeda in Lithuania to the chemical plant in Grodno in Belarus. Preparations for this transport took over two years. The Polish company started cooperating with a Lithuanian and Belarusian company dealing in abnormal load transport in order to obtain the necessary permits. Ultimately, the combination of vehicles used for transport was 75 meters long, 6.8 meters high and 5.6 meters wide (Fig. 2).

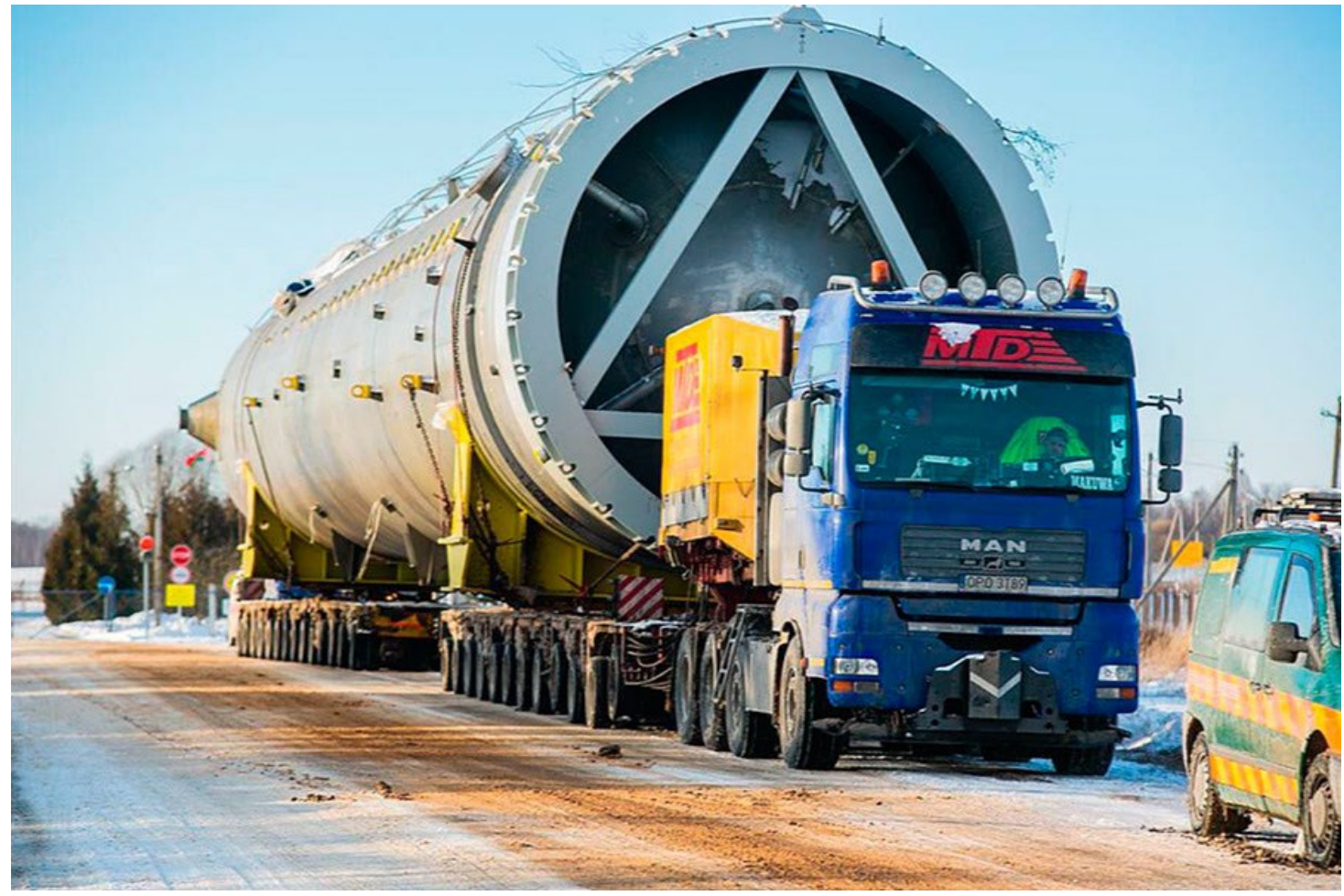

Figure 2. Transport of the reactor by MTD Skuratowicz. Source: http://www.mtdskuratowicz.pl/estapl.html [accessed 15/10/2019].

The route was almost $400 \mathrm{~km}$ long and ran through numerous cities. In order to accurately verify the route necessary to travel, a 5-day test drive was carried out, during which the possible impact on the surrounding infrastructure was assessed. Bridges were evaluated for height and the measured turning radius at many narrow intersections. Transport of the reactor was difficult 
due to atmospheric conditions, because the air temperatures reached -22 degrees, as well as the need to remove road signs, raise railway traction and high-voltage lines (Dolecki, 2017). A combination of vehicles transporting the reactor, due to their dimensions, sometimes covered the entire width of the road, which remarkably hampered communication in a given city. Urban infrastructure was also a problem, as it often had to be corrected during the journey. In many places, in order for the passage to be possible at all, it was necessary to remove road signs and even rebuild part of the road. The reactor itself was transported in two parts to the river port in Czech Mělník. There they were welded and sent on a barge by water to Hamburg. Then by sea it got to Klaipeda. Transport from the port in Lithuania to the chemical plant in Grodno took 10 days. This standard route is done by car in a few hours. Consent to transport had to be expressed by every owner of a road, bridge or high-voltage line running across the designated route. It is also a big challenge from a logistical point of view. The transport took place using two tractors. One pulled the set from the front, the other helped to maneuver the set and pushed it from the back. For organizing and carrying out this transport, MTD Skuratowicz was awarded the "ESTA Awards of excellence 2017" statuette in the category of transport over 120 tonnes during the April edition of the European competition for the oversize transport industry ${ }^{2}$.

\section{Summary}

Abnormal load road transport requires proper organization of transport by a specialized company. It is necessary to use vehicles adapted to high load on individual axles or enabling the transport of cargo exceeding the specified standards. Abnormal load transport on private and public roads requires authorization. Based on the load parameters, the category to which the transport belongs is determined. Each journey of abnormal cargo has a greater or lesser impact on the city's logistics. Often, such transport involves the necessity of temporary removal of road signs, dismantling islands at intersections with circular traffic or lifting power lines. It is not uncommon to turn off the power when traveling under high-voltage wires. An example of abnormal load transport in the context of urban logistics is the transport of a 300 tonne reactor by the Polish company MTD Skuratowicz.

\footnotetext{
${ }^{2}$ Official website of the company MTD Skuratowicz http://www.mtdskuratowicz.pl/esta-pl.html [accessed 15/10/2019].
} 


\section{References}

1. Dolecki, L. (2017). Polska firma zdobyła „Oscara” transportu ponadgabarytowego, https://www.rynekinfrastruktury.pl/wiadomosci/drogi/polska-firma-zdobyla--oskaratransportu-ponadgabarytowego-58177.html, 15.10.2019.

2. Durski, W. (2008). Wybór sposobu transportu ładunku ponadnormatywnego na przykładzie silnika okrętowego. Zeszyty Naukowe Politechniki Poznańskiej, 63, 97.

3. Dyczkowska, J. (2011). Śródlądowy transport wodny a zintegrowany system logistyczny. Logistyka, 2, p. 120.

4. Filina, L. (2008). Ładunki w zintegrowanych systemach transportowych. In: I.N. Semenov (ed.), Zintegrowane łańcuchy transportowe. Warszawa: Difin, 76.

5. Galor, A., Galor, W. (2010). Problematyka krajowego transportu ładunków ponadnormatywnych w aspekcie przewozów w regionie południowego Bałtyku. Logistyka, 2,115 .

6. Górniak, J. (2016). Znaczenie Logistyki Miejskiej w Wybranych Miastach Europejskich. Analiza Porównawcza. Zeszyty Naukowe Politechniki Częstochowskiej, 140.

7. Ładunkoznawstwo. Podrozdz. 3.1. Organizacja przewozów ładunków ponadgabarytowych, 20, http://test.melcom.pl/CSK/images/stories/czytelnia/0170.pdf, 7.10.2019.

8. Meszko, T. (2017). Transport ponadnormatywny - kategorie zezwoleń, http://www.eprzewoznik.pl/aktualnosci-logistyka/transport-ponadnormatywny-kategoriezezwolen/, 15.10.2019.

9. Neider, J. (2012). Transport międzynarodowy. Warszawa: PWE, 160.

10. Rabant, H., Habel, M., Babińśki, Z. (2016). Transport ładunków ponadgabarytowych drogą wodną Wisły. Podstawowe parametry szlaku oraz główne utrudnienia. Prace Komisji Geografii Komunikacji PTG, 19(3), 7-17.

11. Rudziński, R., Kowalczyk, M. (2012). Istota $i$ charakterystyka ładunków ponadnormatywnych, https://repozytorium.uph.edu.pl/bitstream/handle/11331/1025/ Rudzinski_Kowalska_Istota_i_charakterystyka.pdf?sequence=1, 7.10.2019.

12. Salomon, A. Zezwolenia w Transporcie Ladunków Ponadnormatywnych Jako Narzędzie Polityki Gospodarczej Polski, http://studiaimaterialy.pl/wp-content/uploads/2018/01/ salomon.pdf, 128-129, 8.10.2019.

13. Salomon, A. (2010). Przewóz Ładunków Ponadgabarytowych Transportem Kolejowym w Polsce. Zeszyty Naukowe Akademii Morskiej w Gdyni, 54.

14. Szołtysek, J. (2009). Podstawy logistyki miejskiej. Katowice: Akademia Ekonomiczna.

15. Tundys, B. (2012). Wpływ Rozwiązań z Zakresu Logistyki Miejskiej na Kształtowanie Rozwoju Regionów. Zeszyty Naukowe Politechniki Ślaskiej. Gliwice, 93.

16. Waniek, A. (2012). Transport wielkogabarytowy, Materiały dydaktyczne dla nauczycieli., Poznań: Wyższa Szkoła Logistyki, 34.

17. Żurawski, J. (2009). Transport ładunków ponadnormatywnych. In: D. Marciniak-Neider, J. Neider (eds.), Podręcznik spedytora (p. 468). Gdynia: Polska Izba Spedycji i Logistyki. 